\title{
MOMENT-ROTATION CHARACTERISTICS AND FINITE ELEMENT ANALYSIS OF COLD FORMED STEEL CONNECTIONS
}

\author{
Fatih ALEMDAR \\ Hunde Dechasa GELETA \\ Fuad Mohammed ALGAADI
}

Received: 21.09.2020; revised: 14.12.2020; accepted: 18.01.2021

\begin{abstract}
The connections are used to transfer forces and moments due to applied loading. The capability of the connection in the resisting moment is used to classify the types of connections in steelwork particularly for cold-formed steel. Classification schemes based on the total moment-rotation behavior have been developed to aid in the design and analysis of connections. Moment-rotation curve commonly used to describe the connection behavior that can be obtained from either theoretical or experimental study. It is often inappropriate to define the connections as either rigid or pinned due to their high non-linear behavior. Therefore, the lightweight cold formed steel connections have been classified into simple, semi-rigid, and rigid connections according to their strength and rigidity, and discussed in detail. Three-dimensional finite element model of lightweight cold formed steel connection under cyclic loading was generated to investigate and study their behavior. Two lipped sigma sections back-to-back with interconnections are used as beam and column members. Finally, the connection type of lightweight cold formed steel connections have been found to be as semi-rigid, and the key factors influencing stiffness is the bearing forces around the bolt hole.
\end{abstract}

Keywords: Finite element analysis, moment-rotation, cold-formed steel, rigidity

\section{Soğuk Şekillendirilmiş Çelik Bağlantilarin Moment-Dönme Özellikleri ve Sonlu Eleman Analizi}

Öz: Bağlantılar uygulanan yükleme nedeniyle kuvvetleri ve momentleri aktarmak için kullanılır. Taşıma momenti etkisindeki bağlantının kapasitesi, özellikle soğuk şekillendirilmiş çelik için çelik yapıdaki bağlantı türlerini sınıflandırmak için kullanılır. Bağlantının tasarımına ve analizine yardımcı olmak için toplam moment-eğrilik davranışına dayalı sınıflandırma şemaları geliştirilmiştir. Moment-dönme eğrisi, genellikle teorik veya deneysel çalışmadan elde edilebilecek bağlantı davranışını tanımlamak için kullanılır. Doğrusal olmayan davranışlarının yüksek olması nedeniyle bağlantıları ankastre veya sabit olarak tanımlamak genellikle uygunsuzdur. Bu nedenle, soğuk şekillendirilmiş çelik bağlantılar, mukavemetlerine ve rijitliklerine göre basit, yarı rijit ve rijit bağlantılar olarak sınıflandırılmış ve ayrıntılı olarak tartışılmıştır. Çevrimsel yükleme altında soğuk şekillendirilmiş çelik bağlantıların davranışlarını incelemek için üç boyutlu sonlu eleman modelleri oluşturulmuştur. Kiriş ve kolon elemanlar için sırt sırta iki sigma kesit kullanılmıştır. Son olarak, soğuk şekillendirilmiş çelik bağlantıların özelliklerinin yarı rijit olduğu ve rijitliği etkileyen anahtar faktörlerin bulon deliği etrafındaki ezilme kuvvetleri olduğu bulunmuştur.

Anahtar kelimeler: Sonlu eleman analizi, moment-dönme, soğuk şekillendirilmiş çelik, rijitlik

\footnotetext{
* Yıldız Teknik Üniversitesi, Davutpaşa Kampüsü, İnşaat Mühendisliği Bölümü, Esenler, İstanbul 34220

** Yıldız Teknik Üniversitesi, Davutpaşa Kampüsü, İnşaat Mühendisliği Bölümü, Esenler, İstanbul 34220

İletişim Yazarı: Fatih ALEMDAR (falemdar@yildiz.edu.tr)
} 


\section{INTRODUCTION}

Due largely to the wider variety of structural applications relative to a conventional heavy hot-rolled steel structural members, lightweight cold formed steel (CFS) has exhibiting a growing use as a frame structure in the multi-story commercial and residential buildings in the last two decades. Their lightweight, strength, flexibility, and production ease have enabled architects, contractors, and professionals in the field to use products of cold formed lightweight steel that will increase building performance and structural efficiency. At the same time, cold formed lightweight steel members have particular stability problems largely because of the larger widththickness ratio that is not widely found in the hot rolled steel sections (Rondal, 2000; Davies, 2000; Gotluru, 2000). Simple geometric analyses, finite element analyses and finite strip analyses were performed in order to investigate the torsional and distortional behavior of cold formed sections and compared with experimental results (Gotluru, 2000; Put, 1999; Jönsson, 1999).

The hot rolled steel is produced and formed at a high temperature, but cold formed one is at room temperature. A mechanism of producing cold steel members is by shaping the material using either the technique of cold roll forming or the technique of press breaking to get the desired shapes. A cold-formed structural steel member is usually manufactured from strip material, sheet metal, or steel plates (Yu et al., 2020).

The cold formed steel systems have diverse welded and bolted connections. Bolted connections are often applied in building sites because they are easier to build. Rogers and Hancock (1999a) studied to improve the design rules for bolted and screwed connections. Failure modes of these types of connections were investigated (Rogers and Hancock, 1999b; Rogers and Hancock, 2000; Bolandim et al., 2013; Liu et al., 2014Yu and Xu, 2013). In the column to beam joint or overlapped system, gusset plates are the mostly used bolted connecting solution (Tan et al., 2013; Ye et al., 2016). The use of gusset plate can be enhanced by integrating the use of bolted flange-cleat beam-to-column joints in order to achieve a connection considered as simple, fast, cost-effective, and of high quality (Rahbari, 2014). A bolted gusset-plate joint for CFS section was proposed by Bucmys (2015) and the behavior of rectangular gusset plates in CFS connections for beam-column connection with double C-channel (Bucmys, 2017).

The reviews on the development of the cold formed steel members have been significantly increased in the recent years. The reviews focused on the behavior of the cold formed steel sections such as compression of members, distortion and element buckling, curved and corrugated sheets, distortion and torsion, web crippling, construction of plasterboards and composites, and design optimization. The majority of the studies utilized some analytical approximations and purely numerical methods. EN 1993-1-3 standard (2006) and AISI S100 (2007) specification include analytical approximation methods to assess the structural behavior of cold formed steel members. Some numerical methods such as finite element method and finite strip method are used by commercial and free softwares.

The efficiency of the cold-formed steel frames was investigated by a limited number of researchers. Kwon et al. (2006) presented a portal frame connection and system tests consisting of cold-formed parts. Researches indicated that semi-rigid connections formed have large efficiency and can be employed effectively (Kwon et al., 2006). Approaches to strengthening top chords to avoid local buckling were examined (Dawe and Wood, 2006). Raftoyiannis I.G (2005) created an analysis of linear stability to assess the influence of the flexibility of the joint. Numerical results showed the influence on the buckling load by two-parameter successfully in the graphical and tabular form (Raftoyiannis, 2005). Tan S.H (2001) offered nonlinear analysis using an analytical model and thin-walled channels frame experiments having the various configuration of connections. It was necessary to reach a closure among the experimental and theoretical findings. Testing showed that the influence of the thickness of the connection on the 
rigidity of the cold formed steel frames is less important relative to the lip sizes and thickness of the members (Tan, 2001).

To improve the technical application of cold formed steel studies, research into the structural behavior and performance of such frames is still required. A steel frame's structural response is intimately linked to the behavior of its connections (Hancock et al., 2001). In this study, the column and the beam elements are made from a section of double sigma. The material properties of lightweight cold formed steel are utilized as inelastic and connections are defined with bolts. The performance of the connection is examined using computer simulation and found to be semirigid. Finally, the key factor influencing stiffness is obtained to be the bearing forces around the bolt hole.

\section{COLD-FORMED STEEL CONNECTION TYPES BASED ON RIGIDITY}

Connections are categorized by ductility and strength, in which ductility is related to the plastic rotation capacities before failure. The connections' strength category depend on the moment resistance of the beams in the connections. For a connection, rotational capacity and strength are essential parameters. A full-strength connection designed by a plasticity principle can be considered to demonstrate the significance of both strength and rotational flexibility in connections. In this condition, one potential problem may occur when the beam's yield stress exceeds the specific values.

The stability and efficiency of the cold formed steel lightweight structure will be influenced by beam-column connections. A connection transfers force and moment from beam to column. The connections are subjected to axial force, bending moment, shear force, and torsional moments. Compared to bending moment, the torsion effect might be left out, and axial and shear forces can be too minimal. The connections are used to transfer forces and moments due to applied loading. The capacity of the connection in resisting moment will be used to classify the type of connections in steelwork, particularly for cold-formed steel. Connections are classified into three classes based on this criterion: pin connections, semi-rigid connections, and rigid connections. Figure 1 shows the characteristics of moment-rotations of these connections.

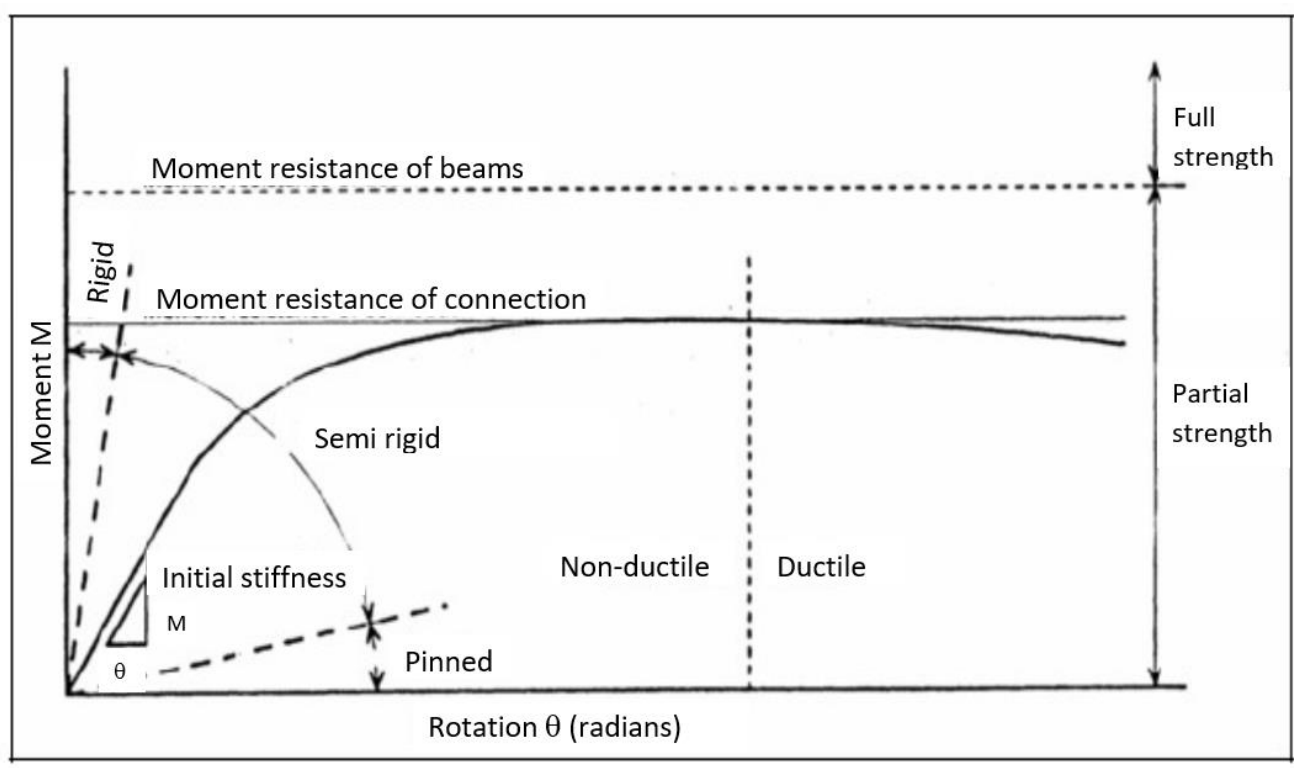

Figure 1:

Moment-rotation characteristics of typical connections (Muhamad, 2010) 


\subsection{Pin Connection}

A pin connection in steel structures is the simplest form of the connection. The kind of connection is used only to withstand shear and normal force. It does not have any moment restraint at the connection. A pin connection is one of those connections that provide zero rotational restraint. In design, it is assumed that pin connections transfer only shear force, from beams to the columns next to a nominal moment and axial load. That means members with a pin connection can rotate freely when the load is applied. The member is supposed to be simply supported when designing pin connections, and caution should be taken in construction so as not to give extra strength to the connection, as the column may fail from buckling due to the extra moment transferred to it.

\subsection{Semi-Rigid Connection}

In practice, the connection often falls into pin and rigid categories although designing pin or rigid connections is common. The majority of the connection does not fall into these two categories because it is hard to maintain this idealized situation, where either there should be no relative rotation for the rigid connections, and no moment is transferred in the pin connections. Most connections transfer some bending moments, and to some degree, rotation occurs. These kinds of connections are called semi-rigid connections, or partial strength connections. The end joints of the member are allowed to rotate but the rotation would be limited. This semi-rigid connection is designed to have an expected interaction degree among the members depending on a joint's moment-rotations behavior.

Connections in semi-rigid category have partial strength and ductility. Generally, the connection can be categorized as ductile, if the maximum rotation is greater than 0,003 radians under the maximum moment. This minimum is increased to 0,004 radians in the seismic zone of a special moment frame since greater ductility is desired (Chen, 2000).

\subsection{Rigid Connection}

Rigid connections are connections with high rigidity that are adequate to preserve the original angle between the intersecting members under the design load. Often known as a full-restraint connection, a rigid connection is able to restrain a moment at the connection. There will be no member rotation at the joint. Rigid connections are designed to be fully restrained, in which ideally there should be no rotation between the connected members. For this connection, full continuity of the connection is preserved where the moment of bending is fully transferred from the beam to the column, along with shear and axial force.

\section{MOMENT-ROTATION (M- $\phi)$ CHARACTERISTICS}

The moment-rotation curve typically used to describe a connection's behavior can be obtained through either theoretical procedure or experimental research. As their behavior is often highly non-linear, the classification of a connection as either rigid or pinned is often inappropriate. In the literature, numerous classification schemes were developed based on the total momentrotation behavior to aid in connection design and analysis. Most of these schemes classify a connection into the following three basic categories according to its moment-rotation characteristic which are flexible, rigid, and semi-rigid.

Semi rigidity concept was known for decades, however, the reason why the term is not used regularly in the frame's practical layout is that its modeling is hard. In a semi-rigid connection, one of the main elements is the moment rotation curve. For other types of connections, the importance of this curve is negligible. For example, a rigid connection is modeled in a beam- 
column connection by setting the boundary conditions such that there is no relative rotation between the column and beam, while in the pin connection, a beam is assumed to be free to rotate from the column. The response is somewhere in between those two scenarios for semi-rigid frames and therefore the moment-rotation curve is so important.

The rotations rise faster for small moment values than large values. The nonlinear behavior is mainly because of connections component's local yield, as well as discontinuities of materials, the concentration of stress, and change in geometry under a loading. The nonlinear behavior may exacerbate in some connection types, particularly in bolt connections, in which slips may cause larger rotations than the one that occurs due to a moment (Chen and Kim, 1989).

Initial stiffness $\mathrm{R}_{\mathrm{ki}}$ is the main parameter of a moment-rotation curve, that is the initial slope of the curve. Unloading stiffness, $R_{k u}$, is a result of load removals or reversals. The tangent stiffness, $R_{k t}$, is an immediate stiffness that falls with increasing moments. The secant stiffness, $R_{k s}$, is an effective stiffness of the connection. All these parameters are shown in Figure 2.

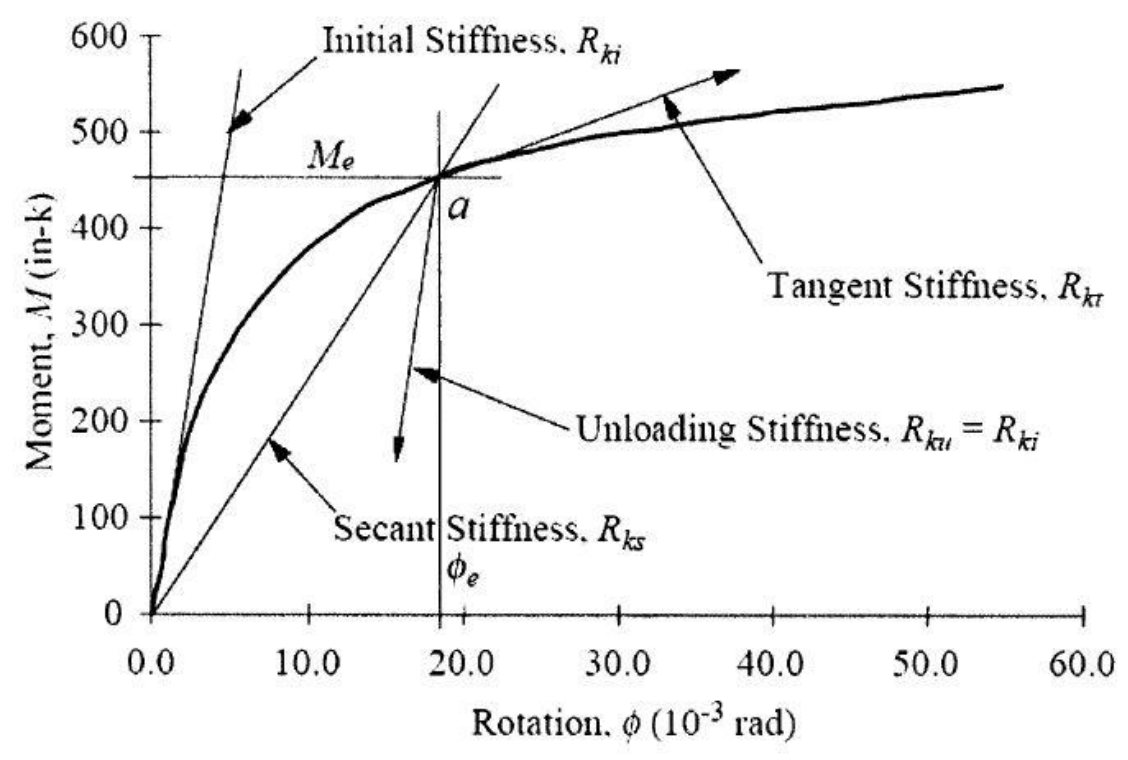

Figure 2:

Moment-Rotation Curve (Leigh, 2006)

A number of different methods can be used to get this moment-rotation curve. One approach is using experimental results. Care should be given to make sure if the condition of a test is exact representations of the design. In converting empirical data of moment rotations to the design values, it is important to use the technique of curve-fitting that approximates a real curve. An equation of the curve approximately is given:

$$
\mathrm{M}=\frac{R_{k i} X \theta}{\left[1+\left(\frac{\theta}{\theta_{0}}\right)^{n}\right]^{\frac{1}{n}}}
$$

where $\theta_{0}$ is the reference rotation, $R_{k i}$ is the connection's initial stiffness and $\mathrm{n}$ is the shape factor (Chen, 2000).

Many connections exhibit nonlinear behavior at small values of moment-rotation right from the start. Usually, the very first tangents at points of zero moment-rotation values give an ideally 
larger initial definition of the stiffness under service level load. Secant stiffness thus can be considered as the index for defining the initial stiffness of the connection. The secant stiffness defined as $\mathrm{K}_{\mathrm{s}}=\mathrm{M}_{\mathrm{s}} / \theta_{\mathrm{s}}$ at the service load where $M_{\mathrm{s}}$ is the moment and $\theta_{\mathrm{s}}$ is the rotation under the service load. The connection rigidity is classified as given in Table 1 . The $\lambda$ is the ratio of the connection secant stiffness to the beam flexural rigidity,

$$
\lambda=K_{S} /(E I / L)
$$

$\mathrm{L}$ is the length of the beam, and EI is the flexural rigidity of the beam.

Table 1. Connection classification according to the stiffness

\begin{tabular}{cc}
\hline Connection & Stiffness \\
\hline Pin & $\lambda \leq 2$ \\
Semi rigid & $2<\lambda<20$ \\
Rigid & $\lambda \geq 20$ \\
\hline
\end{tabular}

The values from 2 to 20 of $\lambda$ indicate the stiffness level of a connection. The connection is more flexible as it approaches 2. Likewise, the connection gets stiffer as it gets closer to 20 .

An alternative approach to the empirically obtained M- $\theta$ curve is the finite element analysis of the connection model. The advantage of the finite element approach is that there's no need to use costly materials and laboratory time. Another advantage is that the model parameters are quickly modifiable, and the actual detail of the connection could be simulated. The disadvantage of the finite element method is that it needs higher levels of knowledge of the simulation of finite element and it consumes time. For the welded connection finite element approach is suitable, however; particularly for the bolted connections it is difficult because bolt has high complexity and variability. For example, the holes of a bolt in plates compared to the diameters of the bolt can be larger in the extents that permit more rotations than expected with a geometric lack of fit (Narayanan, 1989).

\section{FINITE ELEMENT MODEL}

Three-dimensional finite element analysis of lightweight cold formed steel connections under cyclic loading was studied. In this study, ABAQUS finite element program was adopted for the numerical simulation of lightweight cold formed steel connections, as shown in Figure 3. Laboratory testing although play an important role in determining the structural behavior, findings from the simulation of finite element may provide more detailed stress and strain analysis. In ABAQUS modeling process, the connection dimensions, boundary conditions, and material properties used as similar as possible to the experimental set-up model to increase the accuracy. Primary structural members like columns and beams are lipped sigma sections connected back to back (double sections) of the same dimension. The connection between the main columns and beams is formed by using a gusset plate. The section properties are given in Table 2.

Table 2. Section Properties

\begin{tabular}{ccccccc}
\hline Member & Section Type & $\begin{array}{c}\text { Depth } \\
(\mathrm{mm})\end{array}$ & $\begin{array}{c}\text { Thickness } \\
(\mathrm{mm})\end{array}$ & $\begin{array}{c}\text { Width } \\
(\mathrm{mm})\end{array}$ & $I_{x}\left(\mathrm{~mm}^{4}\right)$ & $I_{y}\left(\mathrm{~mm}^{4}\right)$ \\
\hline Beam & Sigma & 200 & 2 & 80 & $495.7 \times 10^{4}$ & $59.2 \times 10^{4}$ \\
Column & Sigma & 200 & 2 & 80 & $495.7 \times 10^{4}$ & $59.2 \times 10^{4}$ \\
\hline
\end{tabular}




\subsection{Modeling The Structure}

The finite element method (FEM) is the leading process in discretization for structural mechanics. Within the physical definition of the FEM, the fundamental principle is that the splitting of a model into a simple geometry non overlapping component known as finite element or element shortly. Separating members into a network of finite elements is one of the most critical steps towards converging into the real behavior of the structure. The response of each element is described in terms of the finite number of degree of freedoms defined at a nodal point as a value of an unknown function.

The unknown is defined by every degree of freedom of the node in the mesh of finite element. In the analysis of the structure nodal degree of freedoms describe components of displacements whereas they describe temperatures in the analysis of heat. The key unknown in the analysis of structure and heat analysis is nodal displacements and nodal temperatures, respectively.

A detailed finite element model was developed to investigate the structural performance of cold formed steel connections under cyclic loading. The model developed takes into consideration the effects of geometric imperfections and nonlinearity of the materials. A full three-dimensional column-beam connection was modeled in ABAQUS (2015) to better understand the detailed structure characteristics as shown in Figure 3. Details of the connection parts are given in Figure 4.

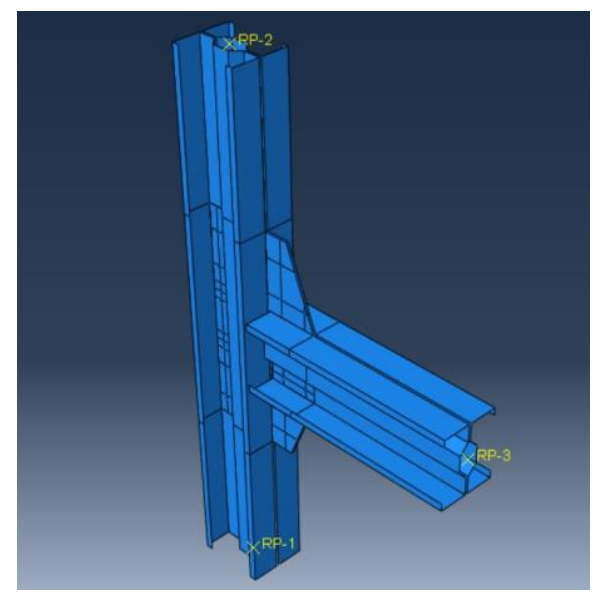

Figure 3:

Model developed in ABAQUS 


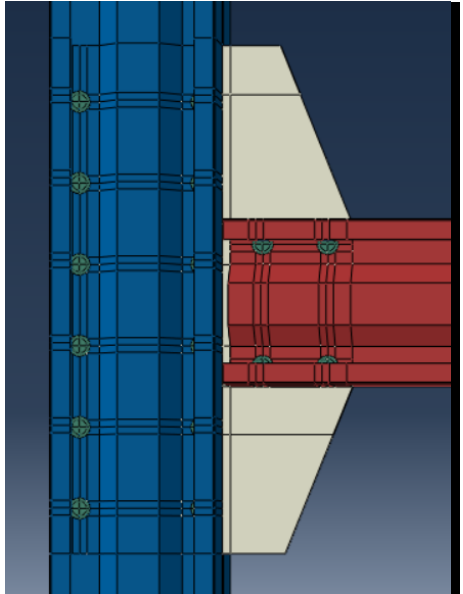

(a)

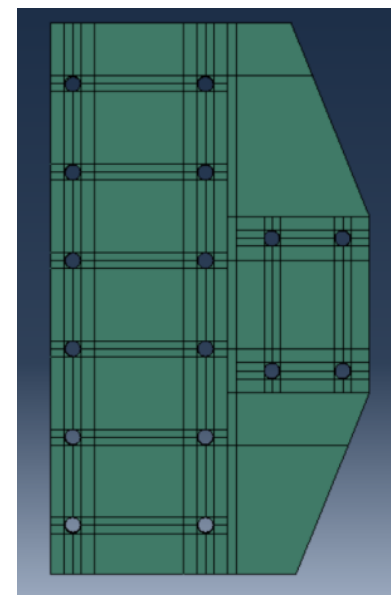

(b)

Figure 4:

(a) Typical column-beam connection, (b) Typical gusset plate

\subsection{Defining Material and Geometric Properties}

Incorporating an accurate description of material behavior is essential to develop reliable finite element models. Inappropriate material behavior representation can severely influence the result extracted from a FEM. In this study, isotropic properties of steel material are assigned to the elements. The modulus of elasticity and Poisson's ratio have been taken, respectively, as 210 $\mathrm{GPa}$ and 0.3 . The density of $7.86 \times 10-9 \mathrm{ton} / \mathrm{mm}^{3}$ is defined. Material characteristics of the cold formed steel used in the model have been determined from tensile testing results of specimens in the laboratory. Figure 5 indicates the average stress-strain relationship used in finite element analysis.

The major components of the steel frame are modeled to reflect the actual behavior of the cold formed steel connection including column, beam, and, gusset plates. A four node nonlinear shell element having reduced integrations points (to reduce the computational cost) was used in the model. A stress-strain curve is the main steel property used to describe its behavior. The stress-strain behavior of cold formed steel is different from that of hot-rolled steel. The yield stress and the ultimate yielding stress are $250 \mathrm{MPa}$ and $375 \mathrm{MPa}$, respectively.

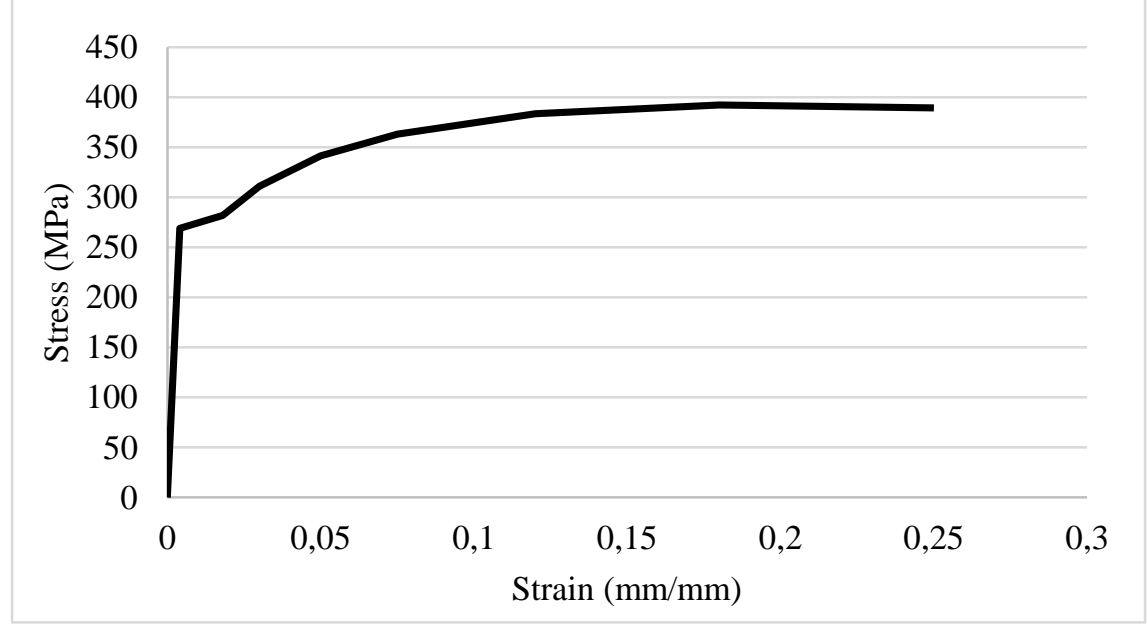

Figure 5:

Stress-strain diagram 


\subsection{Meshing The Structure}

The accuracy in the finite element models is directly related to the mesh used. The mesh in the finite element is often used to divide the model into a smaller domain known as the element that solves the series of equation. Such kinds of equations represent governing equations of interest through the sets of polynomial functions defined in those elements approximately. The simulated solution approaches the true solution as the elements are produced in small size or refined meshing. On the other hand, the expense of computing rises with the rise in the fineness of the mesh. The optimal density of a mesh was calculated through the convergence analysis, which allows a balance between the accuracy and the cost of the solution. In the FE model of the connection, the near-joint regions are created with a finer mesh. It has been found that $25 \times 25$ $\mathrm{mm}$ mesh size for the beam and column and the $10 \times 10 \mathrm{~mm}$ mesh size around the connection provide more accurate results and the computational time is not significantly increased. Figure 6 shows the meshed finite element model of the beam-column subassembly.
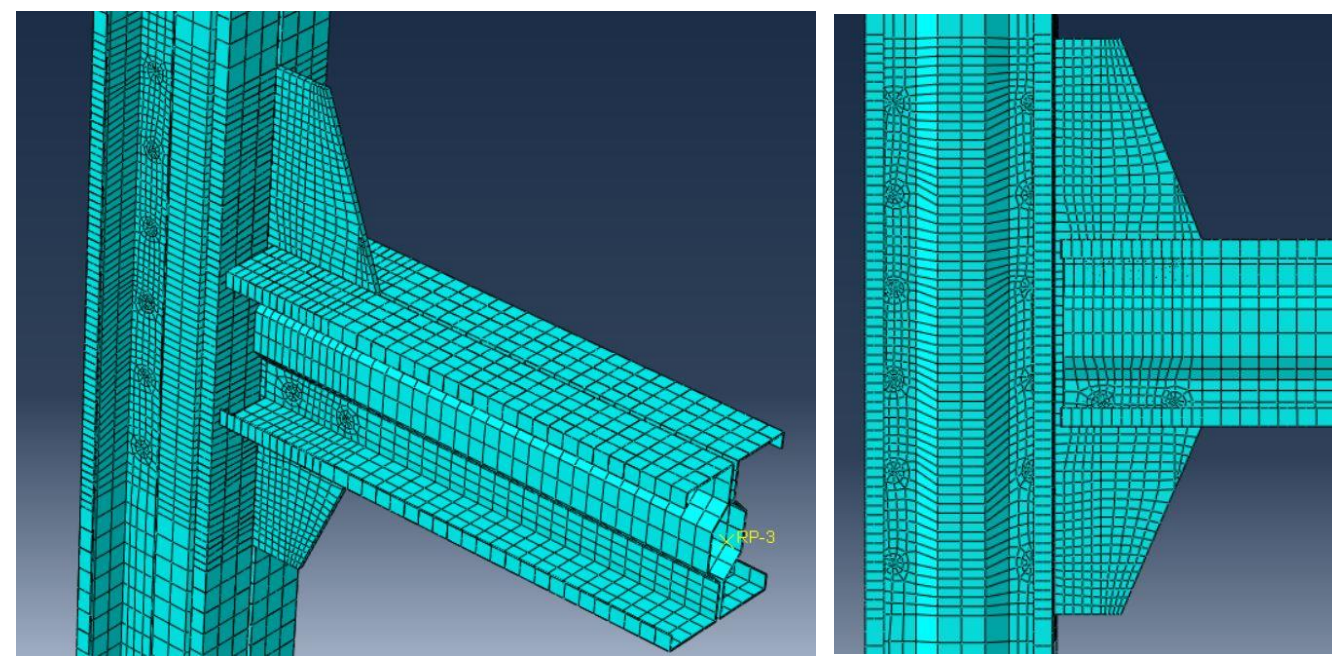

Figure 6:

Finite Element Mesh

\subsection{Contact Definitions between Element Surfaces}

Definition of the interaction between the surfaces of the elements directly affects the analytical results. In the actual connections, the connection of the column, beam, and gusset plate are made using the M12 bolts as shown in Figure 4. In this research, simplifications are made as much as possible while creating the models of the connections. Tie constrain is defined at the interaction of bolts with gusset plate, beam, and column. In this way, it is thought that more accurate results can be obtained. Structural analysis often considers the interaction between two objects. One of these two objects is called master surfaces, another one is called slave surfaces. A surface-to-surface contact command of ABAQUS/Standard is used to define interaction among connection's component. Two surfaces are paired which can interact with each other; one of the surfaces is assigned to be the master surface, and the other is assigned to be the slave surface. In ABAQUS/Standard algorithm of the masters-slaves recognizes a contact surface and apply constraint (pressures) on the slave node to protect them from penetration into the master surfaces.

An edge-to-edge contact element is the kind of element that transfers contact stress over the restricted area by mutually decreasing the edge element node points that fit this element to any edge element selected on the contact surface. The contact element is the element that transfers 
contact stress to the edge of the projection element of a node selected on the contact surface. Contact direction occurs toward the directions of the master surface. The contact surfaces are limited, then the master surface is not penetrated. However, master surfaces will in principle be in contact with the contact surface. Additionally, while surface-to-surface contact mechanics have been established, objects that appear to penetrate to the surface at corner node points where they touch. In current models, the surfaces required to interact with each other include the surfaces of gusset plates, beams, and columns where the bolt lies as shown in Figure 7.

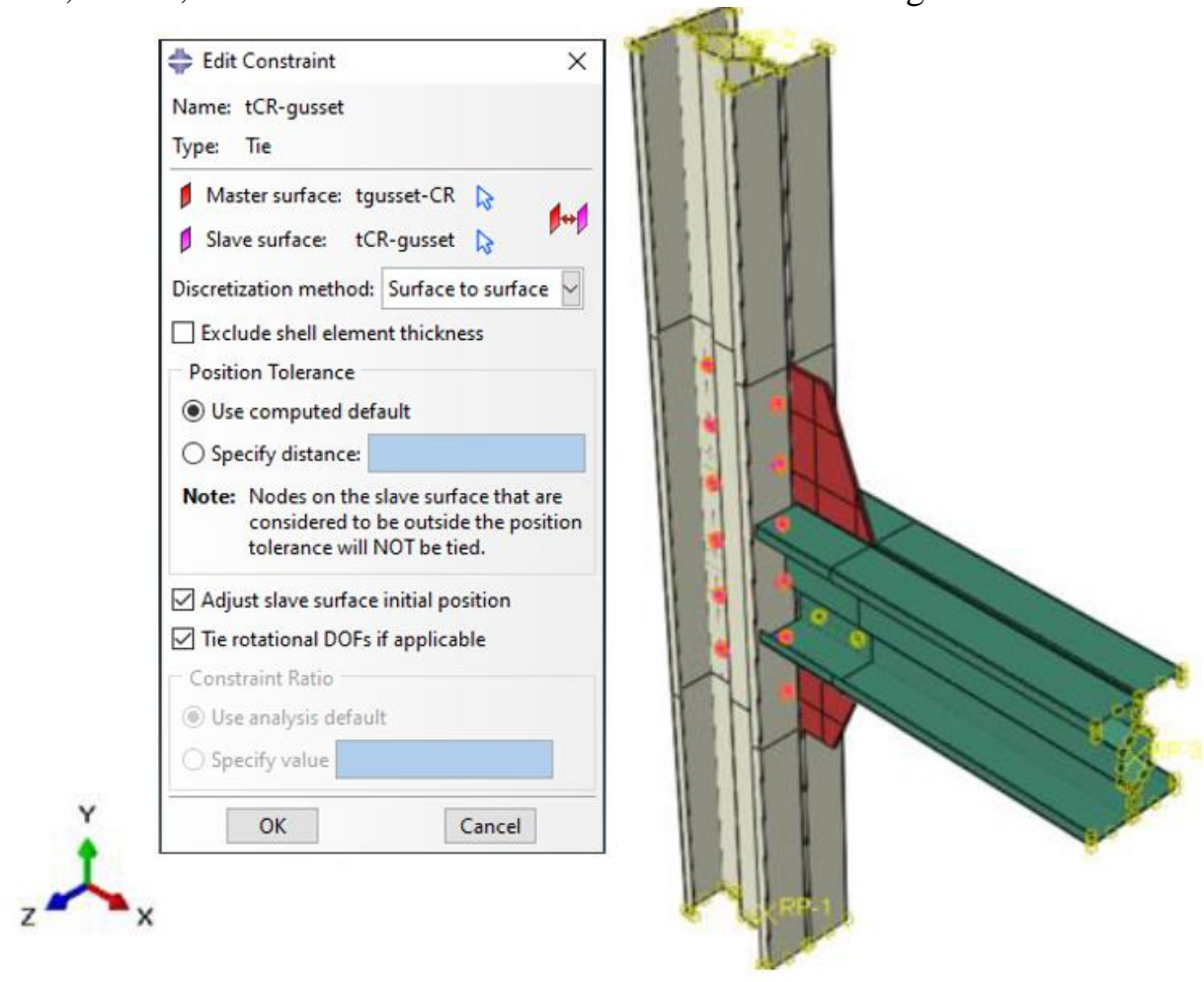

Figure 7:

Contact definition column-gusset plate

\subsection{Loading and Boundary Conditions}

Boundary conditions in the simulation domain are necessary when implementing FEM. Remembering that the finite element approach is basically a numerical approach to solve certain kinds of differential equations called boundary value problems. Column end surfaces were defined as pinned whereas beam end section was constrained in all directions except in vertical direction. Nonlinear finite element analysis was carried out using Static General module by the application of the displacements at a reference point placed on the end sections of the beam as shown in Figure 8. In accordance with FEMA-350 (2000), Table 3 provides the cyclic loading details.

One of the challenges in the nonlinear structural analysis is that the structural rigidity changes as the deformation occurs. Three nonlinearities sources are common in structure modeling. Two of them are material and geometric nonlinearities. The third nonlinearity source is the nonlinearity of the boundary correlated to the boundary condition change in the analysis.

In this study, the General static analysis was employed using displacements controls. ABAQUS/Standard make uses of the method of Newton-Raphson to solve a problem involving nonlinearity. The solution is found in a nonlinear analysis by using the application of displacement 
or load in the increment until the last solutions are achieved. The approximate solution is to sum up all these increments.

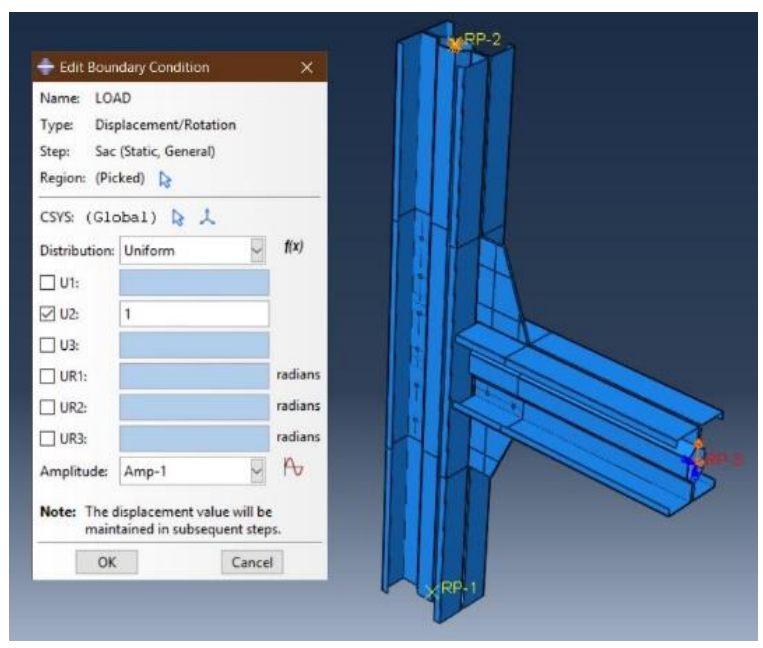

Figure 8:

Loading the Structure and Boundary Conditions

The SAC Joint Venture (SAC), that is supported by the Federal Emergency Management Agency (FEMA), was founded by the Applied Technology Council (ATC), the California Universities for Research in Earthquake Engineering (CUREE), and the Structural Engineers Association of California (SEAOC) in the middle of 1994 in order to examine the damages in the welded steel buildings during the Northridge Earthquake of 1994, and develop maintenance strategies and innovative approach of design in order to reduce damages in the future earthquakes (Lee and Foutch, 2000).

Table 3.Protocol of cyclic loading (FEMA-350)

\begin{tabular}{ccc}
\hline Load Step & $\begin{array}{c}\text { Peak } \\
\text { deformation(rad) }\end{array}$ & Number of cycles \\
\hline 1 & 0.00375 & 6 \\
2 & 0.005 & 6 \\
3 & 0.0075 & 6 \\
4 & 0.01 & 4 \\
5 & 0.015 & 2 \\
6 & 0.02 & 2 \\
7 & 0.03 & 2 \\
8 & 0.04 & 2 \\
9 & 0.05 & 2 \\
\hline
\end{tabular}

\subsection{Result Interpretation}

The criterion of Von Mises Stress failure depends on the Von Mises principle and called the principle of the maximum theory of energy distortion or scalar energy. It is most widely used failure criterion. The theory notes that when a Von Mises Stress at a location equals a stress limit the ductile material begins yielding. The yielding strength is used mostly as limit stress. In the uniaxial result of tensile tests, under complicated loading conditions, a Von Mises Stress can be used to determine yielding of the material. A greater Von Mises value means the material is nearer to the yield point. Von Mises Stress is the measure of non-negative, scalar stresses. Due to the 
fact that many engineering materials exhibit elastoplastic behavior (i.e. steel and aluminum alloy) the members made of such materials can be analyzed by the use of Von Mises Stress.

The distribution of the Von Mises Stresses obtained from the finite element analysis is presented in Figure 9. It is seen that because of the thicker thickness of the plate, in-plane deformation and the stresses formed in the gusset plates are significantly lesser than cold formed steel beams. According to the analysis, model captured a shape and local/distortional buckling positions in the cold formed steel beam successfully. The finite element models can simulate the beam-column connection's cyclic behavior in terms of ductility, stiffness, and degradations of strength. Depending on the beam-column connection's cyclic response a significant amount of energy could be dissipated via the yielding of materials.

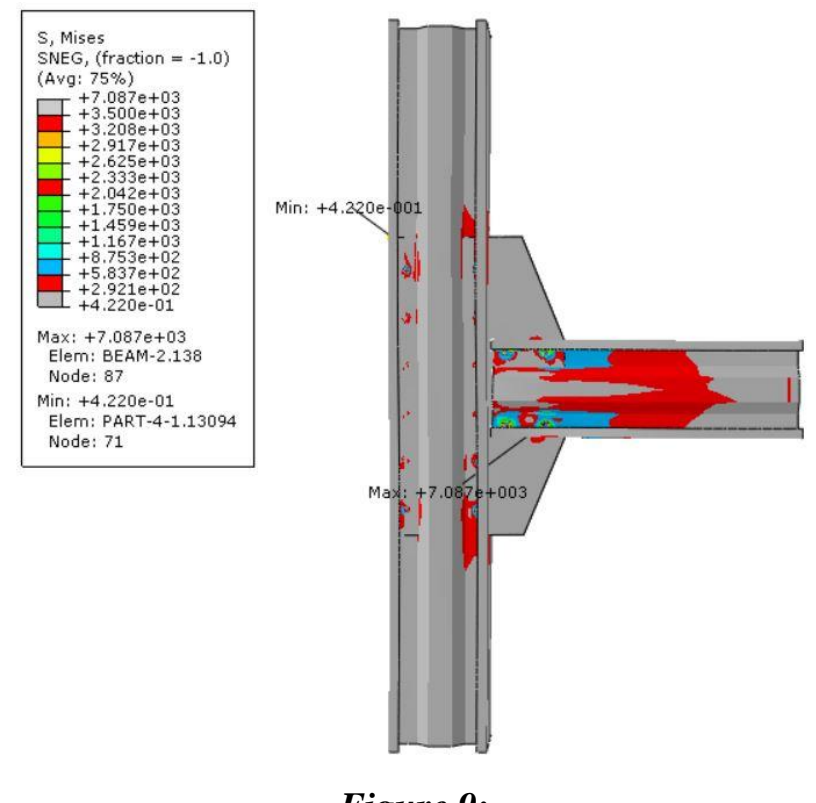

Figure 9:

Von Mises stress distribution along the connection

Various parameters of the performances like moment capacities, stiffness, rigidity, energy dissipation capacity, ductility, yielding moments, and corresponding coefficients of the viscous damping are calculated using moment-rotation results in Figure 10. The connection rotation is determined as the ratio of the displacements of the edge of the beam to the beam length up to the gusset plate. Moment values are calculated at the center of gravity of the connection. The initial stiffness of the bolted cold formed steel connections, $S_{j}$, can be used to classify the connection's rigidity. Table 1 shows the rigidity of various connections depending on the value of stiffness. 


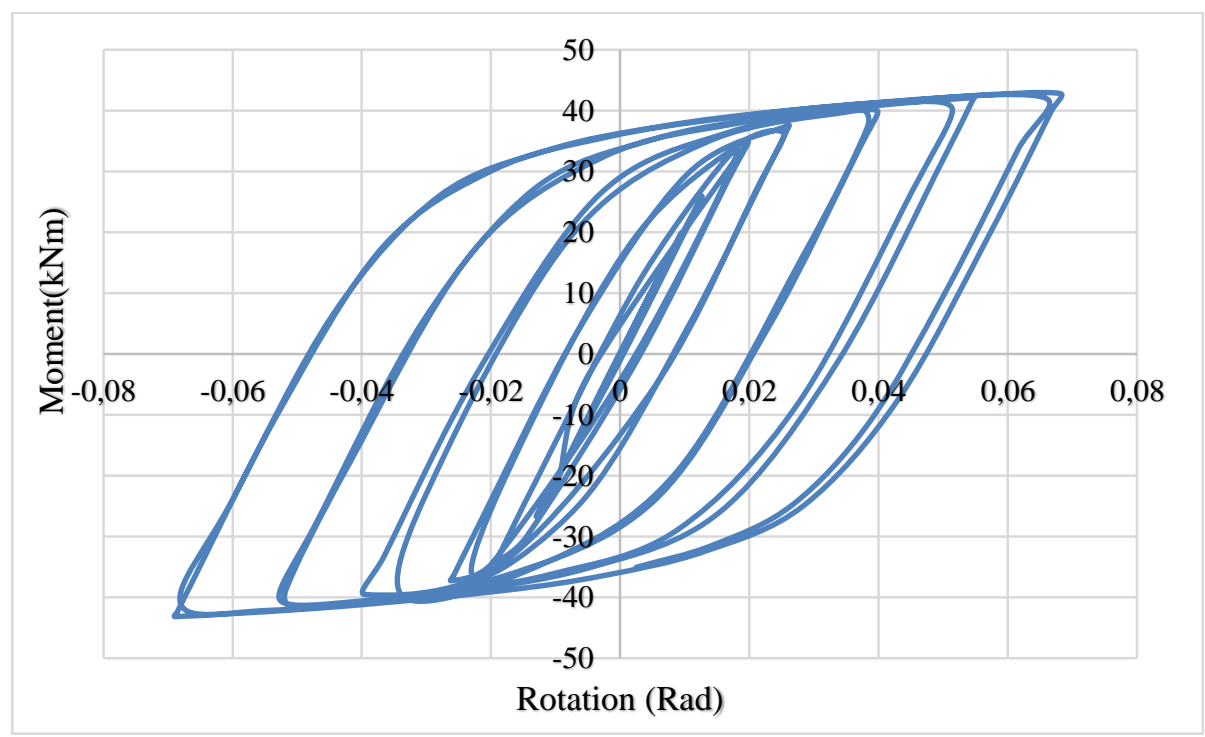

Figure 10:

Moment rotation curve

Depending on the moment-rotation curve above the rigidity and the stiffness of the connection can be derived and the Secant stiffness can be calculated as;

$$
K_{s}=\frac{M_{S}}{\theta_{s}}
$$

where $M_{S}$ is a moment and $\theta_{S}$ is the rotations under service load.

By using the moment-rotation graph $K_{S}=2.91 \times 10^{9}$ is obtained. The next step is determining the rigidity $(\lambda)$ of the connection which is a ratio of secant stiffness of the connection to beam flexural rigidity, $\lambda=K_{S} /(E I / L)$ as described earlier. The length $(\mathrm{L})$ of the beam is 750 $\mathrm{mm}$. The Elastic Modulus and moment of inertia of a beam is $210 \mathrm{GPa}$ and $495.7 \times 10^{4} \mathrm{~mm}^{4}$ respectively. (EI/L) can be calculated as $138.79 \times 10^{7} \mathrm{~N} . \mathrm{mm}$. Finally, the value of rigidity $\lambda=$ 2.11 , the connection can be classified as semi-rigid connections as defined in Table 1 in the previous section.

The global moment-rotation behavior of cold formed steel bolted connections is controlled primarily by the configuration of the bolt distribution, bolt tightening and bearing behavior. The force-displacement curve can be extracted directly from the result of the model using the loadings and nodal displacements as shown in Figure 11. 


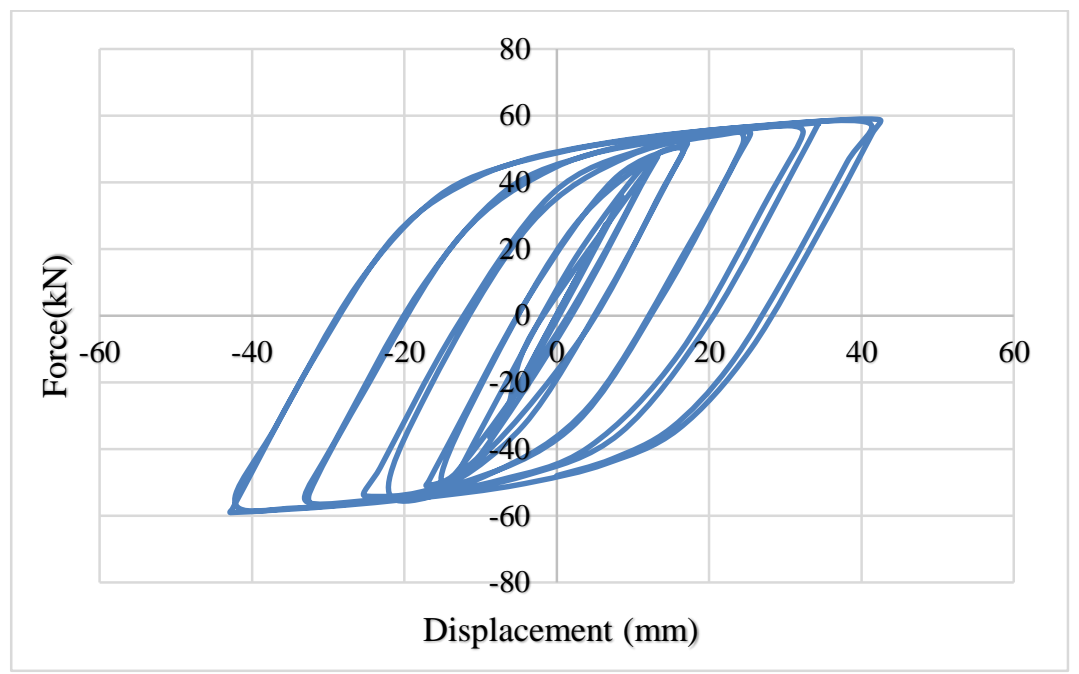

Figure 11:

Force - displacement curve

If the exact stresses at a point were established, only the criterion of Von Mises could be used to estimate the first yield load of the material. Von Mises stress distribution of gusset plates is obtained as shown in Figure 12.
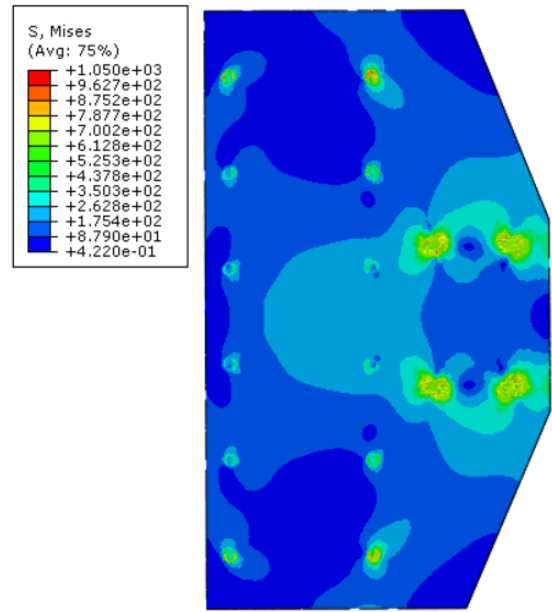

Figure 12:

Von Mises Stress distribution on Gusset Plate

The connections are essential aspects of any building and construction, not just from a point of view of structural behavior but also in connection to production methods. When any failure occurs, it is always best that the structural component fails first than connections. In the situation that the connection fails before the structural member connection fails, then the effects of failure would become severe. There are the parts of connections that designed to fail first, to confirm that this happens in a controlled manner if yielding occurs. It is most essential in the semi-rigid connections since such connections are most probable to stress above yield points and experience plastic deformation. The design should avoid sudden yielding, as well as sudden failure. The connection materials, that involve tensioned bolt and weld, are brittle and may be exposed to sudden failures. Therefore, it should be avoided that the bolt or weld connection in tension to fail. 
In the semi-rigid connection, welded joints are usually avoided, except when they are very standard and certain (Lee and Foutch, 2000).

There are different types of failure modes that occur in bearing type bolted connections. The design specification provides minimum spacing and edge distance for bolt connections to avoid failure of these types. Hancock et al. (2001) suggested that a sheet bearing failures may take place when the spacing and edge distances are high enough to avoid tear-out failures. Bearing failure also results in the widening of a hole on the one side of a bolt, but a sheet materials on the other sides of a bolt are bunched together.

It has been seen from the analyses that the studied bolted cold formed steel connection is mainly prone to tear-out and bearing failures. The two types of failure are shown in Figures 1314 in detail. The tear-out failure mostly happens in the gusset plate and the beam components of the connection while the bearing failure is most commonly seen on the column and the region where the gusset plate is connected to the column. The two types of failure modes are closely related to each other, and there is no direct distinction between them. As the end distance increases, it should be expected that the failure mode would slowly shift from a bolt tear-out to bearing failure.

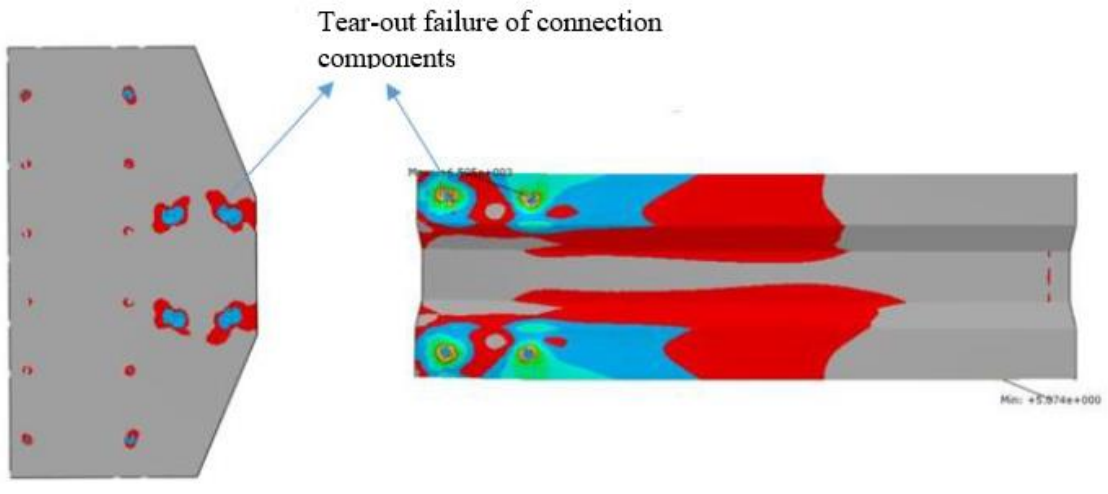

Figure 13:

Tear-out failure
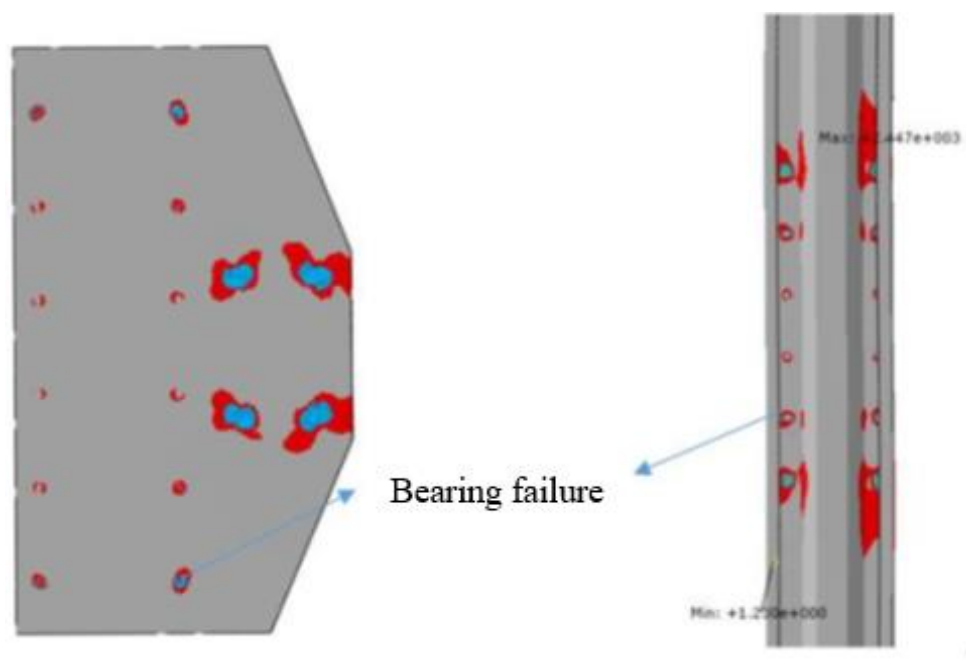

Figure 14:

Bearing failure 


\section{SUMMARY AND CONCLUSIONS}

Three-dimensional finite element model of a cold formed steel connection under cyclic loading was generated to investigate the behavior of the bolted connection. Two lipped sigma sections back-to-back with interconnections are used as beam and column members. The following conclusions are made according to the finite element analysis results:

- The properties of cold formed steel connection has been found as semi-rigid, and a key factor influencing rigidity is the bearing force near the bolt hole.

- The failure modes of the studied connection are shown that the bolted cold formed steel connection is mainly prone to tear-out and bearing failures. The tear-out failure is seen in the gusset plate and beam components of the connection whereas the bearing failure is mostly obtained on the column regions.

- Checking gusset plates for the distribution of elastic stress in the expectation is worthless, since if the plate has flame-cut edges, this has yielded under residual stresses before any external load application. Although modeling in the past has provided safe designs for the elastic stress distribution in gusset plates, the existence of residual stresses and design model inaccuracies make it difficult to predict the actual stress distribution in the gusset plate. Von Mises failure criterion was used to predict the gusset plate's first yield load. It is noted that because of its thicker nature, plane deformations and stress formed in the gusset plates are significantly lesser than the cold formed steel beams.

In general, the bolted cold-formed steel connections are mostly characterized by semi-rigid behavior which provides better stability and performance as compared to pin connections and easier to build as compared to rigid connections. The finite model analysis reveals that modes of failure of bolted cold formed steel lightweight connection are most commonly the tear-out plate failure and bearing failure, it is because of the relative thickness of cold formed lightweight steel connections. As a future research, an experimental study for the analyzed FE model will be done.

\section{CONFLICT OF INTEREST}

The author (s) acknowledge that there is no known conflict of interest or common interest with any institution / organization or person.

\section{AUTHOR CONTRIBUTION}

Fatih Alemdar determination of conceptual and / or design processes of the study, management of conceptual and / or design processes of the study, data collecting, data analysis and interpretation, creating the manuscript, critical review of intellectual content, final approval and full liability of the study. Hunde Dechase Geleta management of conceptual and / or design processes of the study, data collecting, data analysis and interpretation, creating the manuscript, final approval and full liability of the study. Fuad Mohamed Al-Gaadi management of conceptual and / or design processes of the study, data collecting, data analysis and interpretation, creating the manuscript, final approval and full liability of the study. 


\section{REFERENCES}

1. Bolandim, E. A., Beck A. T. and Malite, M. (2013) Bolted connections in cold-formed steel: reliability analysis for rupture in net section, Journal of Structural Engineering, 139(5), 748-756. doi: 10.1061/(ASCE)ST.1943-541X.0000566

2. Chen, W. F. (2000) Practical Analysis for Semi-Rigid Frame Design, World Scientific Publishing Co., River Edge, NJ.

3. Chen, W.F. and Kim, Seung-Eock. (1989) LRFD Steel Design Using Advanced Analysis, CRC Press, Boca Raton, FL.

4. Dawe, J. L. and Wood, J. V. (2006) Small-scale test behavior of roof trusses cold-formed steel, Journal of Structural Engineering, 132(4), 608-615. doi: 10.1061/(ASCE)07339445(2006)132:4(608)

5. FEMA-350, (2000). Prestandard and commentary for seismic rehabilitation of buildings, Federal Emergency Management Agency, Washington, USA.

6. Hancock, G.J., Murray, T. M. and Ellifritt, D.S. (2001) Cold-Formed Steel Structure to the AISI Specification, Macel Dekker, New York.

7. Hibbitt, Karlsson, and Sorensen. (2015) ABAQUS/standard user's manual. HKS Inc., Dallas, USA.

8. Lee, K. and Foutch, D. A. SAC/BD-00/25. Performance Prediction and Evaluation of Steel Special Moment Frames for Seismic Loads, Technical report, SAC Joint Venture, 2000.

9. Kwon, Y. B., Chung, H. S. and Kim, G. D. (2006) Experiments of cold-formed steel connections and portal frames, Journal of Structural Engineering, 132(4), 600- 607. doi: 10.1061/(ASCE)0733-9445(2006)132:4(600)

10. Liu, J., Xu, L. and Fox, S. (2014) Structural strength of lapped cold-formed steel Z-shaped purlin connections with vertical slotted holes, 22nd International Specialty Conference On Cold-Formed Steel Design and Construction, Missouri University of Science and Technology, St Louis, Missouri.

11. Manson, Leigh. (2006). Analysis and comparison of connections in steel structures, Master of Engineering Thesis, Massachusetts Institute of Technology, USA.

12. Muhamad, Khiry, B. A. K. (2010). Analysis of cold- formed steel connections, Master of Engineering Thesis, Universiti Teknologi, Malaysia.

13. Narayanan, R. (1989) Structural Connections: Stability and Strength, Elsevier Science Publishers, New York.

14. Raftoyiannis, I.G. (2005) The effect of semi-rigid joints and an elastic bracing system on the buckling load of simple rectangular steel frames, Journal of Constructional Steel Research, 61(9), 1205-1225. doi: 10.1016/j.jcsr.2005.01.005

15. Tan, S. H. (2001) Channel frames with semi-rigid joints, Computers and Structures, 79, 715725.

16. Rondal, J. (2000) Cold formed steel members and structures-general report, Journal of Constructional Steel Research, 55(1-3), 155-158.

17. Davies, J. M. (2000) Recent research advances in cold-formed steel structures, Journal of Constructional Steel Research, 55(1-3), 267-288. 
18. Gotluru, B. P., Schafer, B. W. and Peköz, T. (2000) Torsion in thin-walled cold-formed steel beams, Thin Wall Structures, 37(2), 127-145.

19. Put, B. M., Pi, Y. L. and Trahair, N. S. (1999) Bending and torsion of cold-formed channel beams, Journal of Structural Engineering, 25(5), 540-546.

20. Jo"nsson, J. (1999) Distortional warping functions and shear distributions in thin-walled beams, Thin-Walled Structures, 33(4), 245-68.

21. Rogers, C. A. and Hancock, G. J. (1999a) Bolted connection design for sheet steels less than 1.0 mm thick, Journal of Constructional Steel Research, 51(2), 123-146.

22. Rogers, C. A. and Hancock, G. J. (1999b) Screwed connection tests of thin G550 and G300 sheet steels, Journal of Structural Engineering, 125(2), 128-136.

23. Rogers, C. A. and Hancock, G. J. (2000) Failure modes of bolted-sheet-steel connections loaded in shear, Journal of Structural Engineering, 126(3), 288-296.

24. Ye, J., Hajirasouliha, I., Becque, J. and Pilakoutas, K. (2016) Development of more efficient cold formed steel channel sections in bending, Thin-Walled Structures, 101, 1-13. doi: 10.1016/j.tws.2015.12.021

25. Rahbari, R., Tyas, A., Davison, J. B. and Stoddart, E. P. (2014) Web shear failure of anglecleat connections loaded at high rates, Journal of Constructional Steel Research, 103, 37-48. doi:10.1016/j.jcsr.2014.07.013

26. Bučmys, Ž. and Daniūnas, A. (2015) Analytical and experimental investigation of coldformed steel beam-to-column bolted gusset-plate joints, Journal of Civil Engineering and Management, 21(8), 1061-1069. doi:10.3846/13923730.2015.1084039

27. Bučmys, Ž. and Daniūnas, A. (2017) Rectangular gusset plate behaviour in cold-formed Itype steel connections, Journal of Archives of Civil Engineering, 63(2), 3-21. doi: 10.1515/ace-2017-0013

28. Tan, C. S., Lee, Y. H., Lee, Y. L., Mohammad, S., Sulaiman, A., Tahir, M. Md. and Shek, P. N. (2013) Numerical simulation of cold-formed steel top-seat flange cleat connection, Jurnal Teknologi, 61(3), 63-71.

29. $\mathrm{Yu}, \mathrm{C}$. and $\mathrm{Xu}, \mathrm{K}$. (2013) Shear strength of a cold-formed steel sheet in bolted connections using oversized holes, Journal of Structural Engineering, 139(5), 860-864. doi: 10.1061/(ASCE)ST.1943-541X.0000561

30. Yu, W. W., LaBoube, R. A. and Chen, H. (2020) Cold Formed Steel Design, Wiley, NewYork.

31. EN 1993-1-3, (2006). Eurocode 3: design of steel structures. part 1.3: general rules - supplementary rules for cold formed members and sheeting, European Committee for Standardization, Brussels.

32. AISI S100-2007- Appendix 1 (2004). Design of cold-formed steel structural members using the Direct Strength Method. In: 2004 supplement to the North American specification for the design of cold-formed steel structures, United States of America: American Iron and Steel Institute, Washington (DC). 